\title{
Fiscal transfers and regional economic growth
}

\section{H. Dawid ${ }^{1}$ ～P. Harting1 | M. Neugart ${ }^{2}$}

\begin{abstract}
In the aftermath of the financial crisis, with periphery countries in the European Union falling even more behind the core countries economically, there have been quests for various kinds of fiscal policies in order to revert divergence. How these policies would unfold and perform comparatively is largely unknown. We analyze four such stylized policies in an agent-based macroeconomic model and study the economic mechanisms behind their relative success. Our main findings are that the core country sharing the debt burden of the periphery country has almost no effect on the growth dynamics of that region, fiscal transfers have a positive short- and long-run impact on per-capita consumption in the target region, and that technology-oriented firm subsidies have the strongest positive long-run impact on competitiveness of the periphery country at which they are targeted. The positive effect of the technology-oriented policy is reinforced if combined with household transfers.
\end{abstract}

\section{1 | INTRODUCTION}

There have been various calls for fiscal policies to foster the economic stance in the periphery countries of the European Union. These quests have highlighted the need to gain a better understanding of the actual effects of interregional fiscal transfers in an economic union that consists of regions that are characterized by heterogeneities with respect to productivity, technology, skill endowments, and still considerably large differences in per-capita income as well as population size.

In this paper we employ a two-region agent-based macroeconomic model (Eurace@Unibi) to study the effects of a set of fiscal policies, taking into account the feedback between technological evolution in a region and (global) competitiveness of local producers as well as the resulting (fiscal) revenues. In the default setting fiscal policy is regional and policymakers finance transfers to households and unemployment payments through taxes on household income and firm profit in their region only. As a result

This is an open access article under the terms of the Creative Commons Attribution-NonCommercial-NoDerivs License, which permits use and distribution in any medium, provided the original work is properly cited, the use is non-commercial and no modifications or adaptations are made.

(C) 2017 The Authors Review of International Economics Published by John Wiley \& Sons Ltd 
of the endogeneity of firms' investment and technology choice the model dynamics in this default setting exhibit a widening of the initial gap between the regions leaving firms in the periphery region at a persistent competitive disadvantage. The malperforming economy in the periphery region implies that the government of that region runs persistent deficits and eventually has access no longer to credit. In the absence of fiscal transfers between regions this results in severe tax increases or cuts in public spending in the periphery region.

Starting from this base scenario the paper studies how fiscal transfers from the technologically more advanced region to the periphery region affects per-capita consumption in both regions. Different variants of the policy, that is, how the money is spent, are compared and economic mechanisms underlying the relative success of the policies are studied. We find that sharing the debt burden of the periphery country has almost no effect on the growth dynamics of that region. Fiscal transfers, our second policy, however, strengthen demand and have a positive short- and long-run impact on per-capita consumption in the target region. Third, we find that technology-oriented firm subsidies have the strongest positive long-run impact on per-capita consumption of the periphery country at which they are targeted and require a relatively small union-wide budget. Finally, the effect of the technology policy on percapita consumption can be leveraged if combined with transfers to households in the periphery region, however, at the cost of a larger budget for the policies.

The model on which we base our analysis captures heterogeneity of firms with respect to the quality of their physical capital and of workers with respect to their specific skills. Specific skills of a worker increase over time if her employer uses technology that is above the worker's current specific skills. Productivity of a firm is determined by a complementarity between the (evolving) quality of its physical capital stock and the specific skills of its workforce. Physical capital is available in different vintages and the firms' vintage choice when investing depends on a comparison of the firms expected returns from different vintages. Because of this, diffusion of new vintages in a technology is driven by the level of investment in physical capital undertaken by firms, which depends on the demand dynamics, and the firms' vintage choice, which is strongly influenced by the specific skills in the firms' workforce. Our policy analysis rests on systematic simulation studies based on large sets of batch runs under the different policy scenarios. Policy effects are estimated using dynamic statistical models recurring to penalized spline methods. Furthermore, the economic mechanisms driving the policy effects are carefully analyzed employing time series of micro- and meso-level variables in the simulation data.

Our simulation model has been shown to reproduce a large set of empirical stylized facts on different levels of aggregation. In this contribution and unlike previous policy analyses that we have conducted with the Eurace@Unibi model (see, e.g., Dawid, Gemkow, Harting, Neugart, Kabus, \& Wersching, 2008; Dawid, Gemkow, Harting, \& Neugart, 2012a, Dawid, Harting, \& Neugart, 2014), we consider a setting where the economy consists of a core region and a periphery region, which differ both with respect to size and their (initial) level of technology. The average quality of the physical capital endowment and the specific skills are initially substantially larger in the core region. Firms from different regions globally compete on product markets but labor markets are assumed to be local. Moreover, there is a home bias for the consumption good produced in the region in which households live.

The policies of the simulation analysis are chosen to reflect European Union initiatives to get fiscal imbalances under control, and a public policy debate that has brought forward various proposals to foster recovery and the catch-up of periphery regions.

First, under the European Stability Mechanism (ESM) put into place in 2012 as a follow up to the temporary funding programs of the European Financial Stability Facility (EFSF) and the European Financial Stabilisation Mechanism, member states can apply for funds when they are in financial difficulties. ${ }^{1}$ Bailouts are conditional on accompanying reform programs for fiscal consolidation, and on member states having signed the European Fiscal Compact, a stricter version of the European Growth 
and Stability Pact, the goal of which it is to avoid excessive fiscal deficits of European Union member states.

Second, in the wake of the financial crisis one could observe a revival in the interest of the effects of activist fiscal policies (Auerbach, Gale, \& Harris, 2010). As part of this development, the policy initiatives by the European member states and the European Commission to get control the financial crisis have been accompanied by an academic discussion over to what extent austerity programs have expansionary or contractionary effects on output (see, e.g., Alesina \& Ardagna, 2010; Jordà \& Taylor, 2016). Center stage to those discussions is generally the multiplier effect of fiscal policies. It, however, turns out that, empirically it is hard to narrow down the actual size of the fiscal multiplier. Using 104 studies on multipliers in a meta-study Gechert (2015) concludes that the multipliers from public spending are significantly positive and on average close to one. Yet, they vary considerably with the study design and the type of spending. While there is a large body of evidence on the likely fiscal effects as the previous study suggests, it seems less known how fiscal policies in an economic union, characterized by considerable heterogeneities in terms of size and factor endowments of the regions, may help to foster economic catch-up in periphery countries, and how core countries will be affected. The exception is a recent contribution by Blanchard, Erceg, and Lindé (2016) who show that an increase in government spending in the core countries of the European Union would have positive and substantial spill-overs on the output of the periphery countries.

Finally, there have been calls for structural reform programs accompanied by infrastructure and R\&D investments (see, e.g., Ioannides and Pissarides, 2015) often labeled a new "Marshall Plan" for Europe. ${ }^{2}$ Larger parts of the so-called cohesion policies target investments and funds of the European Investment Bank could, furthermore, be channeled towards fostering investment activity it is claimed.

It occurs to us that the consequences of the various policy proposals in terms of how they can help to speed up the catching up process of periphery regions is not so well studied. In particular, the longer-run consequences of fiscal policies in comparison, when technology inducing investment impulses are taken into account, seem to be vaguely understood. Thus, we aim for a model-based analysis that may help to better understand the various economic mechanisms and consequences unfolding from different fiscal policies. To this end, we recur to an agent-based macroeconomic model.

Since the early 2000s a number of closed macroeconomic models using an agent-based approach have been developed (see, e.g., Dosi, Fagiolo, \& Roventini, 2010; Delli Gatti, Gallegati, Greenwald, Russo, \& Stiglitz, 2010; Ashraf, Gershman, \& Howitt, 2011; Raberto, Telgio, \& Cincotti, 2012) and several of these have been used to examine different issues in economic policy design. Close to the topic of our paper are, on the one hand, studies of the effects of fiscal policy on growth and, on the other hand, papers exploring the dynamic interaction between regions using an agent-based approach. Russo, Catalano, Gaffeo, Gallegati, and Napoletano (2007) compare the effects of fiscal policies focusing on strengthening demand or fostering technological change in a simple single-region agent-based macroeconomic framework finding that only the latter has positive implications for growth. In the framework of the "Keynes meeting Schumpeter" class of agent-based macroeconomic models Dosi, Fagiolo, Napoletano, and Roventini (2013) observe a positive effect of expansionary fiscal policy, which is oriented towards strengthening demand, for growth and, consistent with these insights, the authors find in Dosi, Fagiolo, Napoletano, Roventini, and Treibich (2015) that policies requiring fiscal cuts in case of high public debts or deficits are detrimental for growth. Multiregional policy analyses using an agent-based approach have, for example, been carried out in Dawid et al. (2012a) studying the effect of labor market integration policies on the convergence of regions, and in Dawid, Harting, and Neugart (2013, 2014), examining the effectiveness of different instruments of cohesion policies for the convergence of regions. Wolf, Fürst, Mandel, Lass, Lincke, Pablo-Martí, and Jaeger (2013) present a multiregional agent-based macroeconomic framework that has been developed to address issues in 
environmental and climate policy. In our contribution, and differing from the existing literature in general and from previous applications of the Eurace@Unibi model for ex-ante policy evaluations, we consider a two-region setup with a core and periphery region in terms of population size.

The outline of the paper is such that we give a nontechnical overview to our simulation model in Section 2. In Section 3 we first describe the experimental setup and then report on our results. The last section concludes.

\section{2 | THE MODEL}

\section{1 | Overall structure}

In a nutshell, the Eurace@Unibi model describes an economy with an investment and a consumption goods sector, and a labor, a financial, and a credit market in a regional context. Capital good firms provide investment goods of different vintages and productivities. Consumption good firms combine capital and labor of varying degrees of general and specific skills to produce a consumption good that households purchase. Households' saved income goes into the credit and financial markets through which it is channeled to firms financing the production of goods.

A complete description of the model as well as a discussion of a Virtual Appliance tool, which allows any researcher to run policy experiments using Eurace@Unibi and to reproduce results in published papers, is provided in Dawid, Harting, Van der Hoog, and Neugart (2016). Because of space constraints no full treatment of the model is given here. Rather, we describe only the main aspects of the model, which are crucial for the understanding of the mechanisms driving the policy results discussed below. The description of the model is to a large extent identical to the ones given in Dawid et al. (2012a, 2013, 2014), since the multiregional setup used here is similar to that underlying those previous analyses. However, the policy agenda of this paper is quite different from the earlier contributions, which focus on the comparison of different variants of cohesion policies. Furthermore, the consideration of the interaction between regions of different size distinguishes this paper from the other studies also from a modeling perspective. Related to this point, the representation of consumer choices, incorporating a bias towards goods produced in their own region, is different from versions of the model used in previous applications.

Capital goods of different quality are provided by capital goods producers with infinite supply. The technological frontier (i.e., the quality of the best currently available capital good) improves over time, where technological change is driven by a stochastic (innovation) process. Firms in the consumption goods sector use capital goods combined with labor input to produce consumption goods. The labor market is populated with workers that acquire specific skills on the job, which they need to fully exploit the technological advantages of the capital employed in the production process. Every time when consumption goods producers invest in new capital goods they decide which quality of capital goods to select, thereby determining the speed by which new technologies spread in the economy. Consumption goods are sold at local market platforms (called malls), where firms store and offer their products and consumers come to buy goods at posted prices. Labor market interaction is described by a simple multiround search-and-matching procedure where firms post vacancies, searching workers apply, firms make offers, and workers accept/reject. Wages of workers are determined, on the one hand, by the expectation at the time of hiring that the employer has about the level of specific skills of the worker, and, on the other hand, by a base wage variable. The base wage is driven by the (past) tightness of the labor market and determines the overall level of wages paid by a particular employer. Banks collect deposits from households and firms and give credit to firms. The interest that firms have to pay on the amount of their loan depends on the financial situation of the firm, and the amount of the loan might be restricted by the bank's liquidity and risk exposure. There is a financial market where shares of a single asset are traded, 
namely an index bond containing all firms in the economy. The allocation of dividends to households is, therefore, determined by the wealth of households in terms of their stock of index bonds. The dividend paid by each share at a certain point in time is given by the sum of the dividends currently paid by all firms. The central bank provides standing facilities for the banks at a given base rate, pays interest on banks' overnight deposits, and might provide fiat money to the government.

Firms that are not able to pay the financial commitments declare illiquidity. Furthermore, if the firm has negative net worth at the end of the production cycle insolvency (bankruptcy) is declared. In both cases it goes out of business, stops all productive activities, and all employees lose their jobs. The firm writes off a fraction of its debt with all banks with which it has a loan and stays idle for a certain period before it becomes active again.

The spatial extensions of the markets differ. The capital goods market is global and, therefore, consumption good firms have access to the same technologies. On the consumption goods market demand is determined locally in the sense that all consumers buy at the local mall located in their region. Supply on this market is global because every consumption good firm might sell its products in all regional markets of the economy. Labor markets are characterized by spatial frictions. It is assumed that workers accept jobs only inside their own region. Finally, firms have access to all banks in the economy, that is, credit markets operate globally. Our setup reflects the consequences of the Single Market Programme of the EU that aims at integrating the goods, services, and financial markets as well as the empirical evidence indicating that labor mobility in Europe is still low. ${ }^{3}$

The choice of the decision rules in the Eurace@Unibi model is based on a systematic attempt to incorporate rules that resemble empirically observable behavior documented in the relevant literature. Concerning households, this means, for example, that empirically identified saving rules are used. Furthermore, purchasing choices are described using models from the marketing literature with strong empirical support. In particular, in several parts of the model, decision-makers are described by logit models. These models are well suited to capture decisions where individuals try to maximize some objective function that depends on some variables common to all decision-makers and are explicitly represented in the model, as well as on aspects that are idiosyncratic to each decision-maker and captured in the model by a stochastic term. With respect to firm behavior we follow the "management science approach", which aims at implementing relatively simple decision rules that match standard procedures of real world firms as described in the corresponding management literature. A more extensive discussion of the management science approach can be found in Dawid and Harting (2012).

Agent actions can be time-driven or event-based, where the former can follow either subjective or objective time schedules. Furthermore, the economic activities take place on a hierarchy of time scales: yearly, monthly, weekly, and daily activities all take place following calendar time or subjective agent time. Agents are activated asynchronously according to their subjective time schedules that are anchored on an individual activation day. These activation days are uniformly randomly distributed among the agents at the start of the simulation, but may change endogenously (e.g., when a household gets reemployed, its subjective month gets synchronized with the activation day of its employer because of wage payments). This modeling approach is supposed to capture the decentralized and typically asynchronous nature of the decision-making processes and activities of economic agents.

\subsection{Agents, markets, and decisions}

\subsection{1 | Output decision and production}

Consumption goods producers need physical capital and labor for production. A firm $i$ has a capital stock $K_{i, t}$ that is composed of different vintages $v$ with $v=1, \ldots, V_{t}$, where $V_{t}$ denotes the number of 
available vintages at time $t$. The accumulation of physical capital by a consumption goods producer follows

$$
K_{i, t+1}^{v}=(1-\delta) K_{i, t}^{v}+I_{i, t}^{v}
$$

where $\delta$ is the depreciation rate and $I_{i, t}^{v} \geq 0$ is the gross investment in vintage $v$.

The production technology in the consumption goods sector is represented by a Leontief type production function with complementarities between the qualities of the different vintages of the capital good and the specific skill level of employees for using these vintages. Vintages are deployed for production in descending order by using the best vintage first. For each vintage the effective productivity is determined by the minimum of its productivity and the average level of relevant specific skills of the workers. Accordingly, output for a consumption goods producer $i$ at time $t$ is given by

$$
Q_{i, t}=\sum_{v=1}^{V_{t}} \min \left[K_{i, t}^{v}, \max \left[0, L_{i, t}-\sum_{k=v+1}^{V_{t}} K_{i, t}^{k}\right]\right] \cdot \min \left[A^{v}, B_{i, t}\right],
$$

where $L_{i, t}$ is labor input, $A^{v}$ is the productivity of vintage $v$ and $B_{i, t}$ denotes the average specific skill level in firms as explained in more detail in Subsection 2.2.3. The fact that the considered production function takes into account the vintage structure of the capital stock and that firms select among different available vintages enables us to capture the effect of workers' skills on the incentives of firms to invest into new technologies (see Subsection 2.2.4).

Once every month each firm determines the quantities to be produced and delivered to each regional mall that the firm is serving. Actual demand for the product of a firm in a given mall and a given month is stochastic (see below) and there are stock-out costs, because consumers intending to buy the product of a firm move on to buy from a different producer in the case where the firm's stock at the mall is empty. Therefore, the firm faces a production planning problem with stochastic demand and stock-out cost. The simplest standard heuristic used in the corresponding operations management literature prescribes to generate an estimation of the distribution of demand and then choose the planned stock level after delivery such that the (estimated) stock-out probability during the following month equals a given parameter value that is influenced by stock-out costs, inventory costs and risk attitude of the firm (see, e.g., Silver, Pyke, \& Peterson, 1998). Firms in the Eurace@ Unibi model follow this simple heuristic, thereby generating a target production quantity for the considered month. Based on the target production quantity, the firm determines the desired input quantities of physical capital and labor. Realizing this production plan might induce the need to buy new physical capital, hire new labor or to obtain additional credit. The firm might be rationed on the labor and credit market, in which case it adjusts its production quantity downwards.

Firms located in the core and periphery region differ in terms of their capital productivity $A$ and the specific skills $B$ of the workers. Initially, as will be explained in more detail in Section 2.4, capital productivity and specific skills are lower in the periphery region but evolve for firms in both regions over time. All firms have access to all vintages of the capital good but labor markets are separated. In terms of consumption goods any firm sells its products in any of the two regions.

\subsection{2 | Pricing decision}

Consumption goods producers set the price of their products once a year, which is consistent with empirical observations (see, e.g., Fabiani et al., 2006). The pricing rule is inspired by the price setting described in Nagle, Hogan, and Zale (2011, ch. 6), a standard volume on strategic pricing in the managerial literature. Firms seek for a profit-maximizing price taking into account the tradeoff between price, sales and costs. 
To obtain an indication of the effect of price changes on sales the consumption goods producers carry out simulated purchase surveys (see Nagle et al., 2011, p. 304). A representative sample of households is asked to compare a firm's product with the set of the currently available rival products for a range of prices. Households' answers are based on the same decision rules they use for their real purchasing decisions. Based on the resulting demand estimations and cost considerations, firms choose the price that maximizes their expected discounted profit stream over their planning horizons. ${ }^{4}$

\subsubsection{Adjustment of specific skills of workers}

The productivity of a worker $h$ is determined by an endogenously increasing specific skill level $b_{h, t}$. It is assumed that during the hiring process the specific skills of job candidates cannot be observed by potential employers. They become observable during the production process. Workers increase the specific skills over time during production by a learning process. The speed of learning depends on the average quality of the technology $A_{i, t}$ used by employer $i$ :

$$
b_{h, t+1}=b_{h, t}+\chi \cdot \max \left[0, A_{i, t}-b_{h, t}\right] .
$$

Here $b_{h, t}$ are the specific skills of worker $h$ in period $t$ and $0<\chi<1$ denotes the speed of adjustment of specific skills. ${ }^{5}$

\subsection{4 | Technological change}

The supply of the capital goods and the process of technological change is modeled in a very simplified way. We recur to a single capital good producer that offers different vintages of the capital good $v=1, \ldots, V_{t}$ that have distinct productivities $A^{v}$. Alternatively, our representation of the supply of capital goods can be interpreted as a market with monopolistic competition structure, where each vintage is offered by a single firm, which uses the pricing rule described below.

New vintages become available over time following a stochastic process. To avoid spurious growth effects, owing to stochastic differences in the dynamics of the technological frontier between runs, we use identical realizations of the stochastic process governing the emergence of new vintages in all runs.

To keep the description of this sector as simple as possible, no explicit representation of the production process and of the needed input factors is introduced. To account for the cost dynamics, it is assumed that the main factor of production costs is the wage bill and, since wages increase on average with the same rate as productivity grows (see Subsection 2.2.6), the growth rate of productivity is used as a proxy for the increase in production costs of the capital goods.

The pricing of the vintages $p_{v, t}$ is modeled as a combination of cost-based $p_{t}^{\text {cost }}$ and value-based prices $p_{v, t}^{\text {value }}$ (see, e.g., Nagle et al., 2011):

$$
p_{v, t}=(1-\lambda) p_{t}^{\text {cost }}+\lambda p_{v, t}^{\text {value }} .
$$

Because of our assumption above, $p_{t}^{\text {cost }}$ increases with the average productivity of the economy. For the value-based price component the average general and specific skills in the economy are determined first. In a next step the discounted productivities for each vintage are calculated for a firm that employs workers whose human capital is equal to the average of the economy. The value-based part $p_{v, t}^{v a l u e}$ is proportional to this estimated effective productivity of the vintage. The motivation for this rule is that the capital good producer tries to estimate the value of each vintage, in terms of effective productivity, for its average customer. Furthermore, it is assumed that the capital good producer is able to deliver any demanded quantity of any vintage. 
The reason why we choose such a simplified representation of the capital goods sector is our focus on the interaction of labor market and consumption goods market dynamics. Therefore, we try to keep all other sectors as simple as possible. Not explicitly modeling the hiring and firing decisions of the capital goods producer has two main implications. First, there are no wage payments from the capital goods producer to households. However, in order to close the model, all revenues of the capital goods producer are channeled back to the households through dividends on the index bonds. Second, the capital goods producer is never rationed on its input markets, in particular on the labor market. The qualitative implication of explicitly capturing the capital goods producer's hiring process would be that in periods when labor market tightness is high there would be a relatively high probability that the capital goods producer is rationed on the labor market. Being rationed the firm would not be able to deliver the full amount of capital goods that is demanded by the consumption goods producers. This would slow down the expansion of these consumption good producers relative to their plans. Such a qualitative effect is already present in the model since consumption good producers need to hire labor themselves whenever they want to expand their production. Through this channel a tight labor market has already a hampering effect on firms' expansion and potential rationing of the capital goods producer would not add a qualitatively different effect.

\subsubsection{Investment and vintage choice}

If consumption good producers have a target output level that cannot be produced with their current capital stock, they acquire new capital. To this end, a consumption goods firm has to choose from the set of available vintages. For the decision in which vintage to invest the complementarity between specific skills and technology plays an important role: owing to the inertia of the specific skill adaptation, the effective productivity of a vintage with $A^{v}>B_{i, t}$ is initially below its quality. It converges to $A^{v}$ over time as the specific skills of workers at the firm catch up to the quality of the vintage. Therefore, the firm computes a discounted sum of estimated effective productivities over a fixed time horizon $S$. The specific skill evolution is estimated for each time step within $[t, t+S]$ using (3), where the firm inserts its average specific skill values. A logit choice model based on the ratio of the estimated effective productivity and price for each available vintage determines which vintage is ordered.

Capital goods are produced on demand, and as consumption goods producers may find it more suitable for their production plans not to employ the latest vintages, the capital good producer keeps on delivering also older vintages as the technology frontier grows. Note, that the way we model the capital good producer it is a proxy for a more differentiated market with different firms supplying different vintages. In this sense, we capture vertical differentiation in the supply of capital goods. Having an elaborated vintage supply is crucial for our contribution given that the dynamics of the model unfold through the interaction of heterogeneous labor and capital as inputs to competing consumption goods producers. In particular, our approach allows the capture of the effects of the skill endowment in a region on the vintage choice of firms and therefore on local technological change, which is an important mechanism in our analysis.

\subsection{6 | Labor market interaction}

If the current workforce of a firm is not sufficient to produce its target output, the firm posts vacancies for production workers. The wage it offers has two constituent parts. The first part is the market-driven base wage $w_{i, t}^{\text {base }}$. The base wage is paid per unit of (expected) specific skills of the worker. If the firm cannot fill its vacancies and the number of unfilled vacancies exceeds some threshold $\bar{v}>0$ the firm raises the base wage offer by a fraction $\varphi$ to attract more workers, that is, 


$$
w_{i, t+1}^{\text {base }}=(1+\varphi) w_{i, t}^{\text {base }} .
$$

The second part of the wage offer is related to an applicant's expected level of specific skills. Since the specific skills represent the (maximal) productivity of the employees, the wage $w_{i, t}$ is higher for higher (expected) specific skills. Because the general skill level of job applicants is not observable, firms use the average specific skills of all their employees to estimate that skill level and offer a wage of

$$
w_{i, t}^{O}=w_{i, t}^{\text {base }} \times \min \left[A_{i, t} \bar{B}_{i, t-1}\right]
$$

where $\bar{B}_{i, t-1}$ are the average specific skills of all employees in the firm. A firm can observe the specific skill levels of all its current employees, however this information will not be transferred to a competitor in case a worker applies there. The wage setting rule used is a reduced form representation of the outcome of firm-level wage negotiations taking into account workers' expected productivity in the firm as well as the workers' outside option. While one might think of other models of wage setting and hiring models, it is crucial for our analysis to capture the link between workers' wages and their productivity in the employer firm as well as the effect of labor market tightness on wages. Both aspects are captured in a parsimonious way in the current setup.

An unemployed worker considers the wage offers posted by a random sample of searching firms in the worker's region and compares them with her reservation wage $w_{h, t}^{R}$. A worker $h$ only applies to firm $i$ if it makes a wage offer $w_{i, t}^{O}>w_{h, t}^{R}$.

The level of the reservation wage is determined by the current wage if the worker is employed, and in the case of an unemployed worker by her previous wage, where the reservation wage declines with the duration of unemployment. The reservation wage never falls below the level of unemployment benefits. If the unemployed worker receives one or more job offers she accepts the job offer with the highest wage offer. In the case where she does not receive any job offers she remains unemployed.

In the case where the workforce of a firm is too large relative to its target output level, the firm adjusts its number of workers. The set of dismissed workers is random. Additionally, there is a small probability for each worker-employee match to be separated in each period. This should capture job separations owing to reasons not explicitly modeled.

\subsubsection{Consumption goods market interaction}

The consumption goods market is modeled as a decentralized goods market. Each local market is represented by a mall at which the consumption goods producers can offer and sell their products to their customers. While firms are free to serve all malls regardless their spatial proximity, households always choose the mall that is located in their region.

Households go shopping once a week and try to spend their entire weekly consumption budget for one good. The consumption budget is determined using a (piecewise) linear consumption rule according to the buffer-stock approach (see Carroll, 1997; Allen \& Carroll, 2001). At the beginning of their shopping procedure they get information about the prices of all available goods at the mall, but they get no information about the available quantities. The decision of which good to buy is described using a logit-choice model with strong empirical foundation in the marketing literature (see, e.g., Malhotra, 1984). We assume two factors influencing consumers' choice function. These two parameters the price sensitivity of consumers and therefore the intensity of competition between the consumption good producers, and the relative preference of households for goods produced in their home region as opposed to the foreign region. The latter is intended to foster the reproduction of stylized facts concerning the fraction of local consumption and can be seen as a representation of differences in taste. Furthermore, 
there is empirical evidence suggesting a home bias in consumers' choice, at least for developed countries, which can be explained by the concept of consumer ethnocentrism (see, e.g., Balabanis \& Diamantopoulos, 2004; Watson \& Wright, 2000). The term consumer ethnocentrism has been introduced by Shimp and Sharma (1987) to represent the responsibility and morality of purchasing foreign-made products and the loyalty of consumers to products manufactured in their home country. ${ }^{6}$

The consumption requests for the different goods are collected by the mall and, if the total demand for one good exceeds its mall inventory level then the mall has to ration the demand. In this case the mall sets a rationing quota corresponding to the percentage of the total demand that can be satisfied with the available goods. Each household receives the indicated percentage of the requested consumption good.

After the shopping activity, rationed households may still have parts of their consumption budget available. Those households have the opportunity to spend the remaining budget for another good in a second shopping loop. In this case the shopping process is repeated as described above.

The production of the consumption goods firm follows a fixed time schedule with fixed production and delivery dates. Even if the mall stock is completely sold out it can only be refilled at the fixed delivery date. Consequently, all the demand that exceeds the expected value of the monthly sales plus the additional buffer cannot be satisfied.

\section{3 | Government}

In each region there is a local government. In the default setting of the model, the regional governments only have redistributional functions by collecting taxes and using the tax revenues to finance unemployment benefits. It is assumed that the regional governments run a balanced budget. To do so, they adjust the tax rates in a way that, retrospectively, the tax rates would have balanced the government expenditures of a given period of length $T^{G}$. More precisely, suppose $G_{r, t-\tau}$ are the governmental expenditures in period $t-\tau$ and $Y_{r, t-\tau}^{G}$ is the tax base from the same period. Then we assume that the tax rate in $t$ is determined according to

$$
\operatorname{tax}_{r, t}=\frac{\sum_{\tau=1}^{T^{G}} G_{r, t-\tau}}{\sum_{\tau=1}^{T^{G}} Y_{r, t-\tau}^{G}} .
$$

The tax base in $t-\tau$ is derived from the tax revenue $T R_{r, t-\tau}$ of this period by computing the following expression:

$$
Y_{r, t-\tau}^{G}=\frac{T R_{r, t-\tau}}{\operatorname{tax}_{r, t-\tau}}
$$

In the policy analysis, we deviate from this default setting essentially in two ways. First, in the baseline policy scenario, we allow one region to temporarily relax the balanced budget rule in order to pay out debt-financed household transfers in that region. Second, in the policy treatment scenarios, we assume a political union of regions and consider different policies that are financed by a union-wide budget supported by contributions from member states.

\section{4 | Parametrization and validation}

In order to determine the values and ranges of parameters to be used in the policy experiments we follow an approach that combines direct estimation of parameters for which empirical observations are available with an indirect calibration approach. This is done in order to establish confidence in the 
ability of the model to capture economic mechanisms that are relevant for real world economic dynamics. Standard constellations have been identified, where values of parameters are chosen to reflect empirical evidence whenever possible and where a large set of stylized facts can be reproduced. Furthermore, the fact that the development of the Eurace@Unibi model follows as far as possible the management science approach, briefly discussed above, provides empirical grounding to individual decision rules, thereby addressing the important point of empirical micro-foundations for modeled behavior.

The set of macroeconomic stylized facts that have been reproduced by the standard constellations of the Eurace@Unibi model includes persistent growth, low positive inflation and a number of important business cycle properties: persistent fluctuations of output; pro-cyclical movement of employment, consumption and investment, where relative sizes of amplitudes qualitatively match those reported, for example, in Stock and Watson (1999), of counter-cyclical movement of wages and firm mark-ups. On the industry level the model generates persistent heterogeneity in firm size, profit rates, productivity and prices in accordance with empirical observations reported, for example, in Dosi, Malerba, Marsili, and Orsenigo (1997). Also labor market regularities, like the Beveridge curve, are reproduced by the model with benchmark parameter constellations. The reader is referred to Dawid, Gemkow, Harting, Van der Hoog, and Neugart (2012b) for a more detailed discussion of this issue. Table A1 in the Appendix provides the list of parameter values used in the simulations underlying this paper.

\section{3 | POLICY ANALYSIS}

\section{1 | Experimental setup}

For the policy analyses we consider a parametrization of the model with a core and more advanced region and a periphery region that is smaller in population size and economically less developed. In particular, the ratio of firms and households is five to one. Moreover, firms in Region 1 have a 50\% higher initial average physical capital and workers an equivalently higher initial level of specific skills.

We contrast a baseline scenario with four different policies that potentially combat regional economic divergence. The narrative for the baseline scenario is that once real consumption goes below $50 \%$ of that of Region 1, Region 2 starts a debt-financed (from third regions) governmental transfer program in order to increase the consumption budget of its households by $10 \%$, and thereby at least partly equalizes the living standards in comparison with Region 1. Once the debt to gross domestic product ratio reaches $150 \%$ in Region 2, access to external financing is stopped. In absence of any union-wide policy initiative the government in Region 2 has to terminate the transfer program and increase taxes in order to repay the debt. Taxes are raised to a level such that debt can be paid back within a projected period of 20 years.

The baseline scenario of a government in Region 2 acting on its own is contrasted with four different union-wide policies all financed jointly according to the shares of the two regions with respect to the union-wide gross domestic product:

(1) Sharing debt repayments;

(2) Continuation of transfers to the households in Region 2 but financed by the union instead of the government of Region 2 only;

(3) Subsidies to firms in Region 2 that spur firms' technology choice;

(4) A combination of subsidies to firms and household transfers.

While admittedly rather stylized, these policies resemble some of the most prominent proposals having been made or policies that have actually been implemented within the framework of the cohesion funds 
or the European Stability Mechanism (ESM). We consider a sharing rule for the debt repayments and transfers that is proportional to the outputs of the regions. For the technology policy we introduce a subsidy for investments of firms in Region 2. The intention of the policy is to subsidize investments only if they are made at the technological frontier. We also want to capture in the model, however, that it is often impossible for the policymaker to determine whether a certain firm investment is indeed at the frontier. Therefore, we assume that with probability $(1-\alpha)$ an investing firm receives the subsidy regardless of its vintage choice, whereas with probability $\alpha$ the subsidy is obtained only if the firm chooses to invest at the frontier. For simplicity it is assumed that the firm knows whether it will be able to receive the subsidy regardless of the chosen vintage when it makes its vintage choices decision. The subsidy covers $25 \%$ of the expenses of the firm for the purchase of the new physical capital. For the experiment we set $\alpha=33$ percent.

For each of the considered policies 24 runs are conducted, with each run encompassing 600 months. In order to avoid any transient effect that might distort our policy analysis, we use an already settled state of the economy as the actual start state of the simulations, where this state is the snapshot of a pre-simulation at $t=1,200$.

In the following analysis, we evaluate the policies statistically by using penalized spline regressions, a technique that can be applied to estimate policy effects dynamically. For each policy scenario, we estimate a spline function representing emerging dynamics of the policy in relation to the baseline scenario, thereby capturing policy effects that evolve or vary over time. A broader discussion regarding the application of spline regressions in the context of estimating policy dynamics can be found in Dawid et al. (2014).

\section{2 | Results}

\subsection{1 | Baseline}

We start the discussion of our results with Figure 1 which shows in panel (a) consumption per capita and in panel (b) productivities for the Region 1 (black line) and Region 2 (red line). As time evolves the two regions diverge in terms of both measures. Region 1 features an increase in per-capita consumption driven by a constant increase in productivity whereas Region 2 stagnates falling ever more behind Region 1 in relative terms.

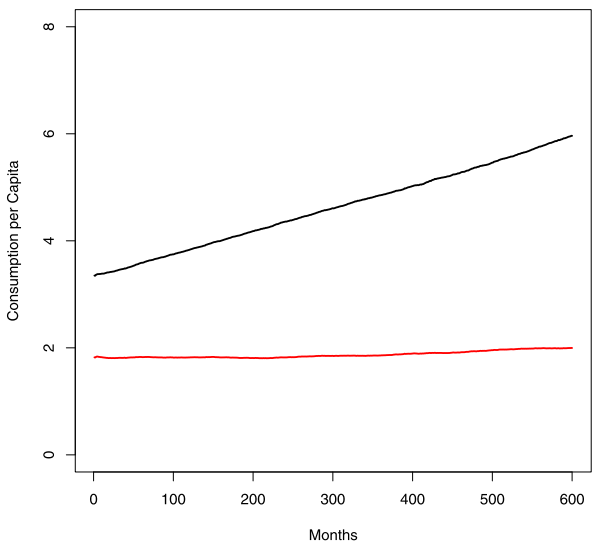

(a)

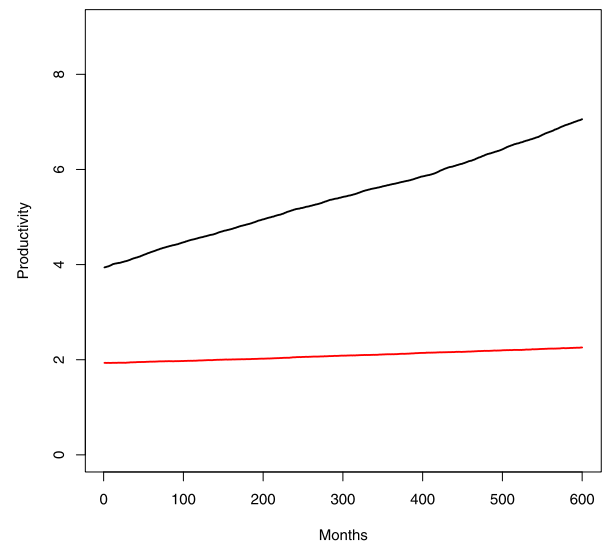

(b)

FIGURE 1 Panel (a): per capita consumption in Region 1 (black) and Region 2 (red); panel (b): productivity in Region 1 (black) and Region 2 (red). [Colour figure can be viewed at wileyonlinelibrary.com] 
Divergence of regions is based on essentially two driving mechanisms. First of all, there is a size effect driving the pricing of capital goods. For a nonperishable and tradable investment good there cannot be price discrimination between firms located in Regions 1 and 2. The investment good producer sets uniform prices for a global market taking into account the value added that an investment good of a better vintage would have for the consumption goods producer. The evaluation of the value added rests on estimates of productivity increases that the consumption good producer would be able to reap if it bought the latest technology. The technologically advanced investment good only fully unfolds its productivity increases if it is run by workers who have the adequate specific skills. Therefore, firms in Region 2 would profit relatively less from purchasing the so-priced capital goods given that their workforce has a lower specific skill level. This sets, and that is the second main force behind divergence, into effect a development where firms in Region 2 do not purchase investment goods of higher quality and eventually the productivity gap of Region 2 to Region 1 increases owing to this path dependency that, initially, was sparked by a lower level of specific skills and technology in Region 2.

In the baseline policy scenario, when Region 2 falls behind Region 1 by 50 percent in terms of percapita consumption, a debt-financed transfer program to lift household consumption is started. Figure 2 compares the relative per-capita consumption levels of Region 2 with Region 1 with and without the transfer policy. As to be expected relative per-capita consumption increases with the launch of the policy (red line). The government is able to relatively improve the living conditions of households in Region 2 whereas it is not able to reverse divergence of per-capita consumption between the two regions.

As already explained in the previous section, we impose an upper ceiling on debt financing of the government in Region 2. It cannot attract external financing of the transfer policy anymore when government debt reaches 150 percent of output. This happens at about month 280. When the debt ceiling is reached, the government ceases the transfer program and increase taxes in order to repay the debt. Consequently, per-capita consumption in Region 2 decreases and, relatively speaking, falls even below the level it would have had without the transfer program installed in the first place. Hence, a policy of fiscal expansion followed by austerity in Region 2 has negative implications for per-capita consumption in the long run.

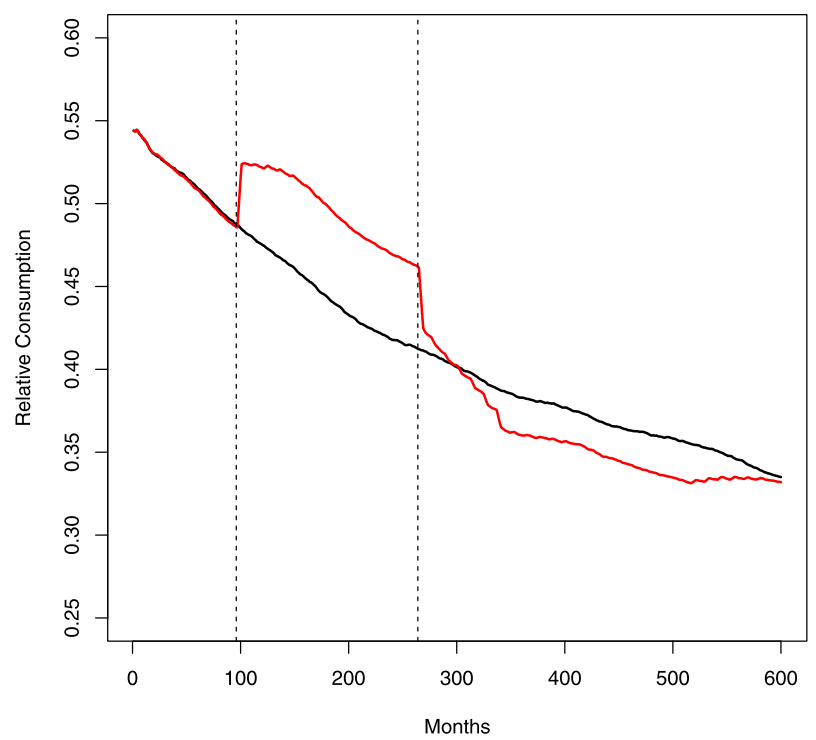

FIGURE 2 Relative consumption in Region 2 without household transfers (black) and with household transfers [Colour figure can be viewed at wileyonlinelibrary.com] 


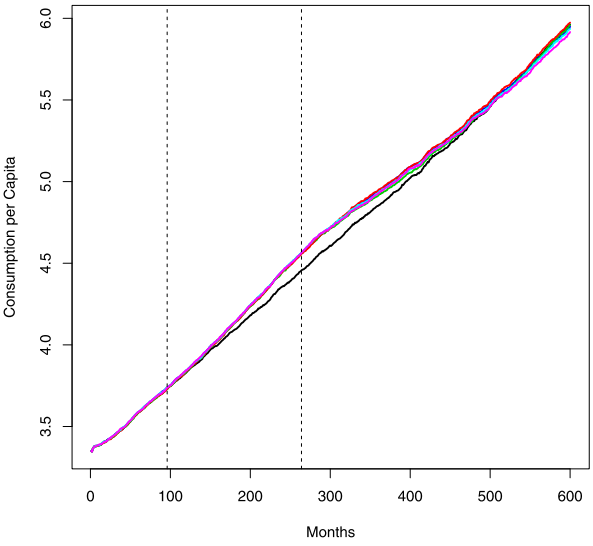

(a)

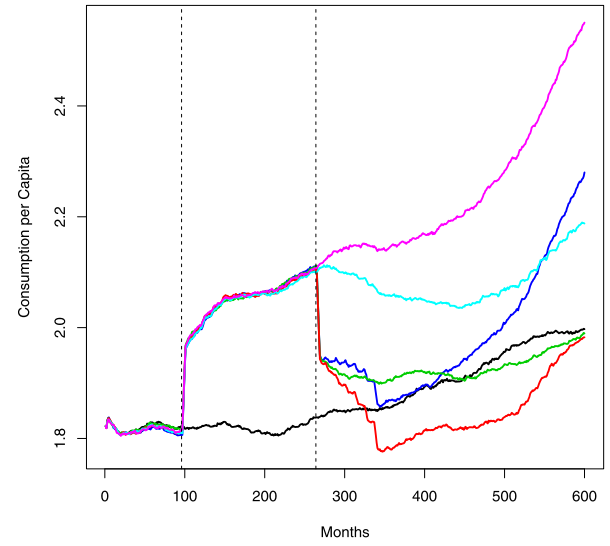

(b)

FI G URE 3 Per capita consumption in Region 1 (panel a) and Region 2 (panel b) under different policy treatments. Color code: black — no policy; red — household transfer; light blue—household transfer by union; green—joined debt repayment by union; blue — technology policy; magenta—combination of household transfer and technology policy [Colour figure can be viewed at wileyonlinelibrary.com]

\subsection{2 | Policy effects}

Now, let us turn to the four union-financed policies outlined earlier on and contrast them to the policy that was debt-financed by the government of Region 2 only. Panels (a) and (b) of Figure 3 show the percapita consumption levels of the two regions for the four policies and the baseline scenario. The black and red line, as in the previous graph, are the baseline scenarios with and without policy intervention by the government of Region 2. Had the government in Region 1 been involved in repaying debts of Region 2 (green line), the slump caused by the tax increase of Region 2 to finance the repaying of debts would not have occurred. Moreover, Region 1, as panel (a) indicates, would have hardly been affected in terms of its per-capita income. Apart from the less dismal performance of Region 2, however, no longer-run gains accrue from a debt sharing policy for the periphery region. In fact, per-capita consumption is the same as in the scenario without any policy intervention (black line). Quite the contrary, running the second policy with fiscal transfers being paid to the households in Region 2 commonly financed by both regions of the union (light blue line) does better than all policies studied so far. Higher per-capita consumption can be sustained beyond the times where per-capita consumption with debt sharing had already decreased to the no-policy intervention level. There also occur some gains of that policy for Region 1. Thirdly, subsidies paid to the firms in Region 2 to incentivize them to invest into better technology commonly financed by both regions, lead to per-capita consumption levels that are initially lower than with fiscal transfer policies but are paying out in the longer run (blue line). Again, Region 1 seems to slightly profit from this policy. Finally, combining transfers to households and subsidies to firms' capital investment goods purchases is achieving the largest gains in terms of per-capita consumption.

In order to elicit the comparative policy effects in terms of their quantitative size and statistical significance we plot in Figure 4 per-capita consumption levels using splines. The time series have to be read as the absolute effect on per-capita consumption of the four policies in relation to Region 2 repaying its debts out of its own pockets. All policies have small negative effects on per-capita consumption in Region 1. By the end of the simulation period Region 1 has a per-capita income of six units, and the most detrimental policy would decrease per-capita consumption in Region 1 by about 0.06 units, that is, 1 percent. For Region 2 all policies have a sizable and statistically significant positive effect on percapita consumption. Moreover, as already hinted to by the previous graph some policies perform significantly better than others. Sharing the debt burden helps Region 2 only slightly during the repayment 


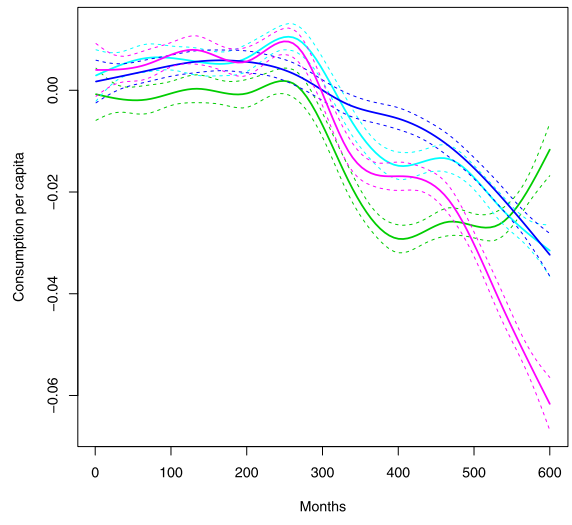

(a)

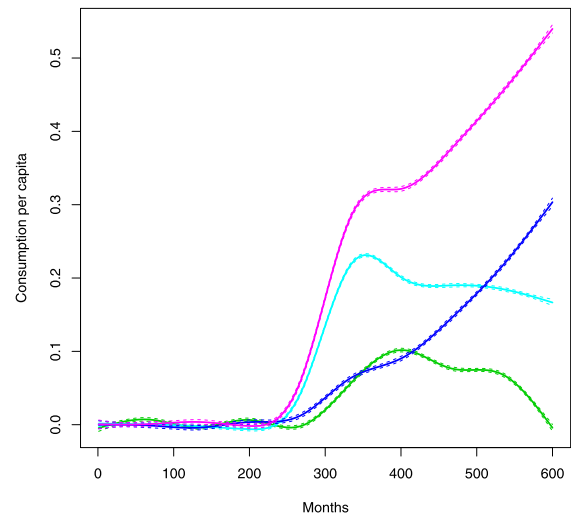

(b)

F I G U RE 4 Spline smoothed policy effects of different policy treatments on per capita consumption in Region 1 (panel a) and Region 2 (panel b). Color code: light blue—household transfer by union; green—joined debt repayment by union; blue—-technology policy; magenta—combination of household transfer and technology policy [Colour figure can be viewed at wileyonlinelibrary.com]

period but has no longer-term effects on per-capita consumption (green line). As already indicated, paying subsidies to incentivize investments in capital goods has longer-run advantages. What performs best is the combination of the subsidy with a joined financing of household transfers. Here, the policy effects is about 0.5 units compared with per-capita consumption of less than two by the end of the simulation period had Region 2 been left alone paying back its debts.

Contrasting the effect of the policies on output as shown in Figure 5 with the effects on consumption reveals that the transfer policy, while having decreased consumption in Region 1, has a positive effect on output in that region. Moreover, for Region 2 there is no output effect while it increases consumption. For the policy incentivizing technology adoption, consumption and output effects are both positive in Region 2, and both negative in Region 1.

What stands behind those findings? The reason why subsidies to firms in Region 2 in order to incentivize them to purchase higher vintage investment goods does so well is rather straightforward

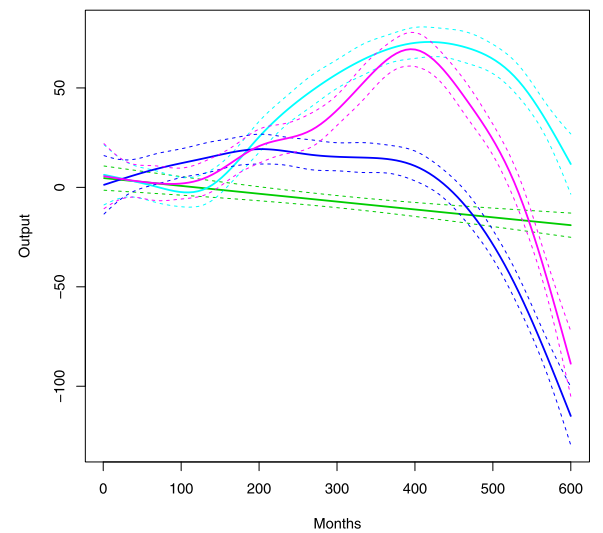

(a)

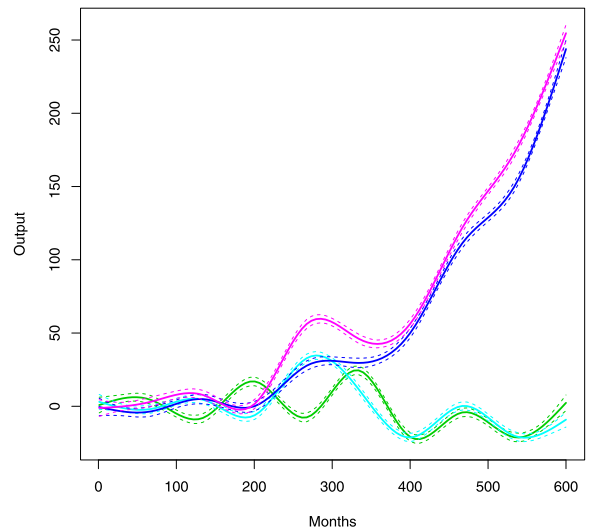

(b)

FIGURE 5 Spline smoothed policy effects of different policy treatments on total output produced in Region 1 (panel a) and Region 2 (panel b). Color code: light blue — household transfer by union; green — joined debt repayment by union; blue-technology policy; magenta — combination of household transfer and technology policy [Colour figure can be viewed at wileyonlinelibrary.com] 


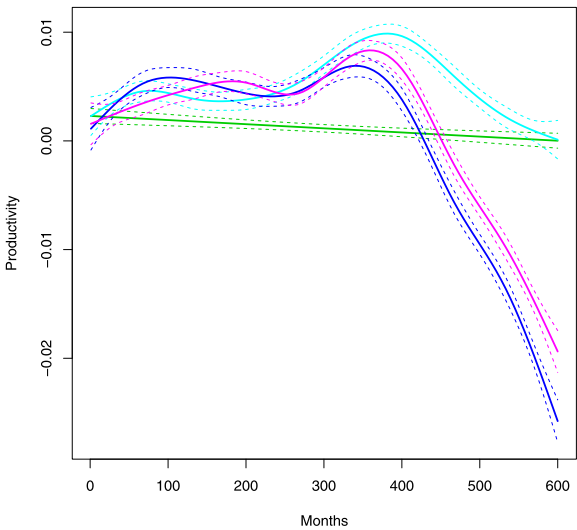

(a)

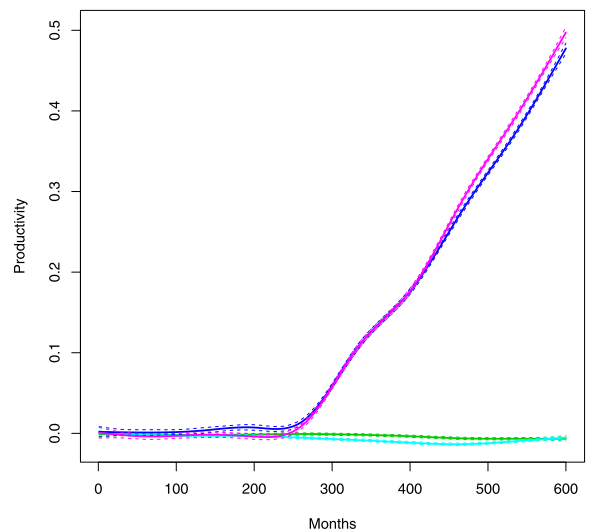

(b)

F IG URE 6 Spline smoothed policy effects of different policy treatments on the average productivity in Region 1 (panel a) and Region 2 (panel b). Color code: light blue—household transfer by union; green—joined debt repayment by union; blue — technology policy; magenta—combination of household transfer and technology policy [Colour figure can be viewed at wileyonlinelibrary.com]

and illustrated in Figures 6 to 7. Those subsidies actually achieve the goal of equipping firms in Region 2 with better technology. This makes them more productive and improves their relative competitiveness with respect to firms located in Region 1. Consequently, their exports boost, generating more demand for firms in Region 2, which spurs further investments and productivity increases. Household transfers jointly financed by both regions essentially have no effect on productivity in Region 2, although they raise demand to firms located in Region 2 which makes those firms invest more. However, there is a countervailing effect rendering this policy less effective than the technology policy for Region 2. As firms in Region 2 are trying to meet the higher demand for their product by expanding production they are decelerated by frictions in the labor market. As they are hiring more workers wage demands increase, which eventually translate into the prices of the products produced by firms located in Region 2. It lowers their competitiveness relative to firms in Region 1, and a share of the policy induced higher demand is met by firms producing in Region 1. This can be seen by the decline of

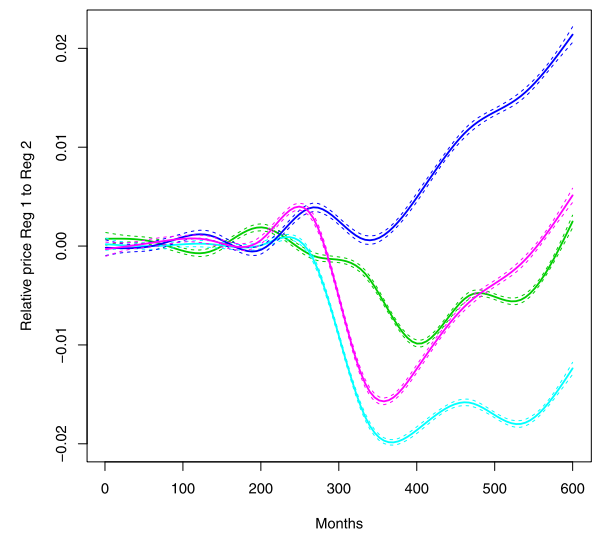

(a)

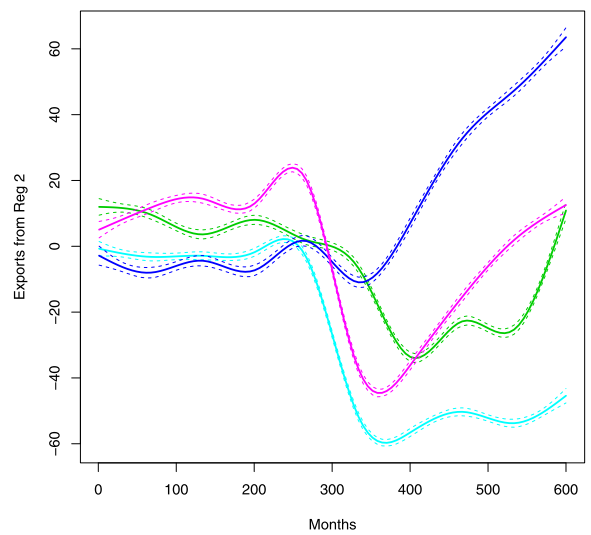

(b)

F IG U RE 7 Spline smoothed policy effects of different policy treatments on the average price of firms in Region 1 relative to the average price of firms in Region 2 (panel a) and the export volume from Region 2 to Region 1. Color code: light blue—household transfer by union; green—joined debt repayment by union; blue—-technology policy; magenta—combination of household transfer and technology policy [Colour figure can be viewed at wileyonlinelibrary.com] 


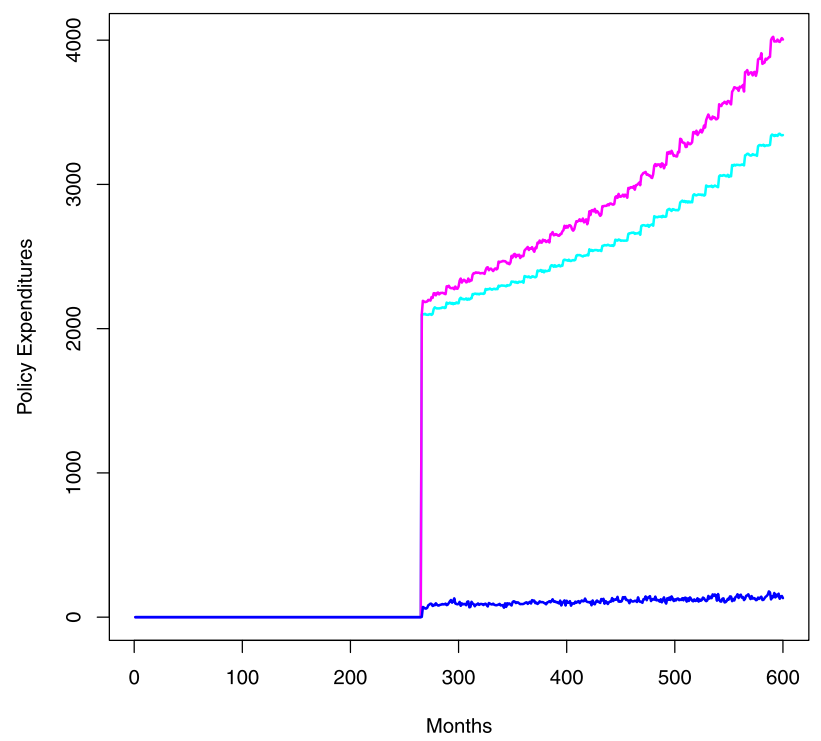

FI G URE 8 Volume of the policies: blue — tech policy; light blue—household transfer; magenta—technology plus household transfer [Colour figure can be viewed at wileyonlinelibrary.com]

exports of Region 2 to Region 1 in Figure 7 for the transfer policy. As some of the production is transferred to Region 1 by that policy there is no positive effect on the technology choice in Region 2 although one could initially observe an expansion of the capital stock. In addition, there is a very small positive effect on the technology choice in Region 1 so that the technology gap is even slightly increasing between the two regions for that policy scenario.

The effects of the technology policy differ from those of the transfer policy, as the pressure on prices, which originates from the frictions on the labor market under the transfer policy, is alleviated. This is due to the fact that productivity of firms in Region 2 is positively influenced under the technology policy. Under this policy firms in Region 2 become more competitive eventually so that they achieve an increase in exports to Region 1, thereby not only increasing consumption but also output. The higher competitiveness of firms in Region 2 harms Region 1 in terms of lowering its output in the longer run.

As household transfers are combined with the technology policy, the negative effect of the demand policy on the competitiveness explained above is strongly reduced, see panel (b) of Figure 6. Contrary to the isolated application, the transfer policy when combined with the technology policy has a strictly positive effect on productivity in Region 2 even slightly increasing the effect of the technology policy. As firms in Region 2 become more competitive in the longer run, output shifts away from Region 1, which reduces investments there, and eventually the quality of the capital stock in Region 1.

Finally, in contrast, the debt sharing policy does neither improve technology adoption in Region 2 nor has a significant effect on household consumption, none of the above outlined mechanisms unfold rendering it ineffective in terms of raising (relative) living standards.

TABLE 1 Initialization of capital stock, skills, and size of regions

\begin{tabular}{lcc|} 
& Region $\mathbf{1}$ & Region $\mathbf{2}$ \\
\hline Initial quality of capital stock & 1.5 & 1.0 \\
\hline Initial specific skills & 1.5 & 1.0 \\
\hline Number of households/firms & $4000 / 200$ & $800 / 40$
\end{tabular}


As a final remark, we turn attention to the fiscal burden of the policies. Figure 8 compares the expenditures for the policies. If fiscal transfers to households in Region 2 are commonly financed, this uses up considerable larger resources than paying out subsidies to spark investment into higher quality technology of firms in Region 2.

\section{CONCLUSIONS}

In the aftermath of the financial and fiscal crisis we have been observing a further economic disintegration in the European Union. Countries in the periphery have been lacking the growth rates to keep up with the economic development of the core countries. Per-capita income differentials rather increased than narrowed as a consequence. The disappointing economic performance has also caused concerns about the stability, economically and politically, of the European Union. Various proposals have been entering the policy discussion. These range from unionizing debt repayments to transfers to periphery countries either in terms of increasing households' disposable incomes or incentivizing investments to increase firms' productivities. It occurs that there is hardly any model-based analysis that would try to evaluate ex-ante the likely consequences of these various policy proposals on economic outcomes in the core and periphery countries for the medium as well as longer run.

We adapted the Eurace@Unibi model that has been used for ex-ante policy evaluations in various other contexts to take into account the divergent economic sizes and productivities in a stylized coreperiphery setting. Starting from a baseline scenario with a highly indebted periphery, we compare four distinct policies in terms of the medium and long-run consequences for output and consumption in the core and periphery. We find that a successful policy needs to target technology adoption, in our case by incentivizing firms to purchase investment goods of higher quality. Only by doing so, labor productivity can be eventually increased leading to higher per-capita consumption in the longer run. Compared with the other simulated policies, a technology-oriented policy also seems to be less resource intensive than sharing debt repayments or transfers to households increasing their net income. Fostering technology adoption in the periphery has negative effects on output and consumption in the core. In our simulated setting of an economic union, those effects, however, seem to be relatively small compared with the gains that could be achieved in terms of convergence of economic conditions.

\section{ACKNOWLEDGMENT}

The paper has benefited from comments and suggestions by participants of the following Conferences: Computing in Economics and Finance (Bordeaux, 2016), Schumpeter Conference on Evolutionary Economics (Montreal, 2016), Artificial Economics Conference (Rome, 2016), GeoComplexity Conference (Heraklion, 2016). This research has been supported by the European Union's Horizon 2020 grant No. 649186-Project ISIGrowth and the COST Action IS1104 "The EU in the new economic complex geography: models, tools and policy evaluation."

\section{NOTES}

${ }^{1}$ See http://www.esm.europa.eu/for more details on the ESM.

${ }^{2}$ See, for example, the interview with Barry Eichengreen at http://www.handelsblatt.com/politik/international/barryeichengreen-zur-schuldenkrise-griechenland-braucht-einen-marshallplan/12006770.html

${ }^{3}$ In 2010, only 2.8 percent of working-age European citizens lived in another EU member state (European Commission, 2011).

${ }^{4}$ We like to point out that the implementation of the firms' demand estimation differs from the standard Eurace@Unibi model, as described in Dawid et al. (2016), in order to allow region-specific demand estimations of firms. Formally, 
following Harting (2015), it is assumed that firms do not only estimate the impact of their price on demand but also that of a second product property, namely the regional origin.

${ }^{5}$ In the general version of the model heterogeneity of the learning speed across individuals is captured and it is assumed that the speed of adjustment positively depends on the level of general skills (see Dawid et al., 2016). In the context of the policy analysis in this paper we abstract from the explicit representation of the heterogeneity of general skills, since empirical evidence (Eurostat Education and Training Data http://ec.europa.eu/eurostat/web/education-and-training/data/ main-tables) suggests that there are no systematic differences between EU core and periphery regions with respect to formal education.

${ }^{6}$ The French, German, and Italian market for new cars in 2015 can serve as an example that illustrates the concept of a home bias. While French car manufacturers such as Renault, Citroen and Peugeot achieve a total market share of 56 percent in their domestic market, German brands such as VW, Mercedes, Audi, and BMW dominate the German market for new cars with a total market share of more than 60 percent. The Italian market is more open to foreign brands but the local producer Fiat is the undisputed market leader with a market share of about 20 percent.

\section{REFERENCES}

Alesina, A., \& Ardagna, S. (2010). Large changes in fiscal policy: Taxes versus spending. Tax Policy and the Economy, 24(1), 35-68.

Allen, T., \& Carroll, C. (2001). Individual learning about consumption. Macroeconomic Dynamics, 5(2), $255-271$.

Ashraf, Q., Gershman, B., \& Howitt, P. (2011). Banks, market organization, and macroeconomic performance: An agent-based computational analysis (NBER Working Paper No. 17102). Cambridge, MA: National Bureau of Economic Research.

Auerbach, A. J., Gale, W. G., \& Harris, B. H. (2010). Activist fiscal policy. The Journal of Economic Perspectives, 24(4), 141-163.

Balabanis, G., \& Diamantopoulos, A. (2004). Domestic country bias, country-of-origin effects, and consumer ethnocentrism: A multidimensional unfolding approach. Journal of the Academy of Marketing Science, 32(1), 80-95.

Blanchard, O., Erceg, C., \& Lindé, J. (2016). Jump-starting the Euro Area recovery: Would a rise in core fiscal spending help the periphery? NBER Macroeconomics Annual 2016, 31(1), 103-182.

Carroll, C. (1997). Buffer-stock saving and the life cycle/permanent income hypothesis. The Quarterly Journal of Economics, 112(1), 1-55.

Dawid, H., Gemkow, S., Harting, P., \& Neugart, M. (2012a). Labor market integration policies and the convergence of regions: The role of skills and technology diffusion. Journal of Evolutionary Economics, 22(3), 543-562.

Dawid, H., Gemkow, S., Harting, P., Neugart, M., Kabus, K., \& Wersching, K. (2008). Skills, innovation and growth: An agent-based policy analysis. Jahrbücher für Nationalökonomie und Statistik/Journal of Economics and Statistics, 228(2-3), 251-275.

Dawid, H., Gemkow, S., Harting, P., Van der Hoog, S., \& Neugart, M. (2012b). The Eurace@Unibi model: An agent-based macroeconomic model for economic policy design (Bielefeld Working Papers in Economics and Management No. 05-2012). Bielefeld, Germany: University of Bielefeld.

Dawid, H., \& Harting, P. (2012). Capturing firm behavior in agent-based models of industry evolution and macroeconomic dynamics. In G. Bünsdorf (Ed.), Applied evolutionary economics, behavior and organizations (pp. 103-130). Cheltenham, U.K.: Edward Elgar.

Dawid, H., Harting, P., \& Neugart, M. (2013). Cohesion policy and inequality dynamics: Insights from a heterogeneous agents macroeconomic model (Bielefeld Working Papers in Economics and Management No. 26-2013). Bielefeld, Germany: University of Bielefeld.

Dawid, H., Harting, P., \& Neugart, M. (2014). Economic convergence: Policy implications from a heterogeneous agent model. Journal of Economic Dynamics and Control, 44(C), 54-80.

Dawid, H., Harting, P., Van der Hoog, S., \& Neugart, M. (2016). A heterogeneous agent macroeconomic model for policy evaluation: Improving transparency and reproducibility (Bielefeld Working Papers in Economics and Management No. 06-2016). Bielefeld, Germany: University of Bielefeld. 
Delli Gatti, D., Gallegati, M., Greenwald, B., Russo, A., \& J. Stiglitz (2010). The financial accelerator in an evolving credit network. Journal of Economic Dynamics and Control, 34(9), 1627-1650.

Dosi, G., Fagiolo, G., Napoletano, M., \& Roventini, A. (2013). Income distribution, credit and fiscal policies in an agent-based Keynesian model. Journal of Economic Dynamics and Control, 37(8), 1598-1625.

Dosi, G., Fagiolo, G., Napoletano, M., Roventini, A., \& Treibich, T. (2015). Fiscal and monetary policies in complex evolving economies. Journal of Economic Dynamics and Control, 52(C), 166-189.

Dosi, G., Fagiolo, G., \& Roventini, A. (2010). Schumpeter meeting Keynes: A policy-friendly model of endogenous growth and business cycles. Journal of Economic Dynamics and Control, 34(9), 1748-1767.

Dosi, G., Malerba, F., Marsili, O., \& Orsenigo, L. (1997). Industrial structures and dynamics: Evidence, interpretations and puzzles. Industrial and Corporate Change, 6(1), 3-24.

European Commission (2011). Employment and social development in Europe 2011 (Report from the European Commission). Brussels: European Commission.

Fabiani, S., Druant, M., Hernando, I., Kwapil, C., Landau, B., Loupias, C., .., Stokman, A. (2006). What firm surveys tell us about price-setting behavior in the euro area. International Journal of Central Banking, 2(3), 3-47.

Gechert, S. (2015). What fiscal policy is most effective? A meta-regression analysis. Oxford Economic Papers, 67 (3), 553-580.

Harting, P. (2015). Stabilization policy and long-term growth: An agent-based policy analysis (Bielefeld Working Papers in Economics and Management No. 06-2015). Bielefeld, Germany: University of Bielefeld.

Ioannides, Y. M., \& Pissarides, C. (2015). Is the Greek debt crisis one of supply or demand? Brookings Papers on Economic Activity, 28, 349-173.

Jordà, Ò., \& Taylor, A. M. (2016). The time for austerity: Estimating the average treatment effect of fiscal policy. The Economic Journal, 126(590), 219-255.

Malhotra, N. (1984). The use of linear logit models in marketing research. Journal of Marketing Research, 11(1), $20-31$.

Nagle, T., Hogan, J., \& Zale, J. (2011). The strategy and tactics of pricing: A guide to growing more profitably. Upper Saddle River, NJ: Pearson Prentice Hall.

Raberto, M., Telgio, A., \& Cincotti, S. (2012). Debt, deleveraging and business cycles: An agent-based perspective. Economics, The Open-Access, Open-Assessment E-Journal, 6. https://doi.org/10.5018/economics-ejournal.ja. 2012-27

Russo, A., Catalano, M., Gaffeo, E., Gallegati, M., \& Napoletano, M. (2007). Industrial dynamics, fiscal policy and R\&D: Evidence from a computational experiment. Journal of Economic Behavior and Organization, 64(3), 426-447.

Shimp, T. A., \& Sharma, S. (1987). Consumer ethnocentrism: Construction and validation of the CETSCALE. Journal of Marketing Research, 24(3), 280-289.

Silver, E., Pyke, D., \& Peterson, R. (1998). Inventory management and production planning and scheduling. Chichester, UK: John Wiley \& Sons.

Stock, J., \& Watson, M. (1999). Business cycle fluctuations and U.S. macroeconomic time series. In J. Taylor \& M. Woodford (Eds.), Handbook of macroeconomics (Vol. 1, pp. 3-64). Amsterdam: Elsevier.

Watson, J. J., \& Wright, K. (2000). Consumer ethnocentrism and attitudes toward domestic and foreign products. European Journal of Marketing, 34(9-10), 1149-1166.

Wolf, S., Fürst, S., Mandel, A., Lass, W., Lincke, D., Pablo-Martí, F., \& Jaeger, C. (2013). A multi-agent model of several economic regions. Environmental Modelling \& Software, 44, 25-43.

How to cite this article: Dawid H, Harting P, Neugart M. Fiscal transfers and regional economic growth. Rev Int Econ. 2018;26:651-671. https://doi.org/10.1111/roie.12317 


\section{APPENDIX : SIMULATION PARAMETERS}

The following table gives the default parameter setting used in the policy experiments discussed in the paper.

TABLE A1 Values of selected parameters

\begin{tabular}{|c|c|c|}
\hline Parameter & Description & Value \\
\hline$u$ & Wage replacement rate & 0.70 \\
\hline$T^{\mathrm{G}}$ & Government time horizon in months & 72 \\
\hline$\delta$ & Capital depreciation rate (monthly) & 0.01 \\
\hline$\gamma^{C}$ & Intensity of consumer choice: price & 16.0 \\
\hline$\gamma^{L}$ & Intensity of consumer choice: home bias & 4.0 \\
\hline$\rho$ & Discount rate (monthly) & 0.005 \\
\hline$S$ & Firm time horizon in months & 12 \\
\hline$\lambda$ & Bargaining power of the capital goods producer & 0.5 \\
\hline$\varphi$ & Wage update & 0.005 \\
\hline $\bar{v}$ & Number of unfilled vacancies triggering wage update & 2 \\
\hline$\psi$ & Wage reservation update & 0.01 \\
\hline$\chi$ & Specific skills adaptation speed & 0.03703 \\
\hline
\end{tabular}

